\title{
Development of Framework for Talent Management in the Global Context
}

\author{
Mohammed Al Haziazi \\ Faculty of Business Studies, Arab Open University, Muscat, Oman \\ Email: alhaziazi@aou.edu.om
}

How to cite this paper: Al Haziazi, M. (2021). Development of Framework for Talent Management in the Global Context. Open Journal of Business and Management, 9, 1771-1781.

https://doi.org/10.4236/ojbm.2021.94096

Received: June 6, 2021

Accepted: July 16, 2021

Published: July 19, 2021

Copyright (อ 2021 by author(s) and Scientific Research Publishing Inc. This work is licensed under the Creative Commons Attribution International License (CC BY 4.0).

http://creativecommons.org/licenses/by/4.0/ (c) (i) Open Access

\begin{abstract}
Talent management practices ensure that the right people want to join the company and effectively bring new, talented workers into the company. The purpose of this paper is to contribute to the development of framework for talent management under the current global context. The paper is built on the analysis and synthesis of scientific literature which enables to describe the phenomenon of the talent management. The advancement in the field of talent management, this paper tried to analyze the talent management in global context from four perspectives such as human centric culture, digital skills, employee wellbeing and human resource analytics and develop a framework. Talent management has emerged as the biggest challenge facing organizations. Today, human capital at every level is considered more important than ever to organizations that hope to raise their competitiveness, both globally and locally, as all organizations face a global competition. For countries operating in multinational environments, the framework and measurement approach can be applied to understand unique challenges in the current global scenario that may reflect both the capabilities and behaviors of human capital in those countries. The talent management framework also suggests that future research work will help the global organization to face the challenges in the talent management in the competitive environment.
\end{abstract}

\section{Keywords}

Talent Management, Digital Skills, Human Centric, HR Analytics, Employee Wellbeing

\section{Introduction}

Talent is attributed to those individuals that have the potential to make a positive impact on "organizational performance either through their immediate contribu- 
tion or in the longer term by demonstrating the highest levels of potential" (Ford et al., 2010). Identifying and acquiring talent has become difficult; it is more difficult to retain them because talents are very mobile. Workforces around the world have become larger, increasingly diverse, more educated, and more mobile (Briscoe et al., 2009). There need to develop and promote talent has become an important feature in the contemporary business environment (Garg \& Rani, 2014). The effective management of human talent is a significant source of competitive differentiation vital to the success of organizations (Caligiuri \& Tarique, 2009). Based on the increased need for basic skills and advanced skills level, talent management has emerged in many works of literature that emphasizes the importance of human capital as a first step in gaining and sustaining a global competitive advantage (Dayel et al., 2020). Talent management is concerned with the systematic identification of positions which are key to the organization's competitive advantage sustainably over time, coupled with the identification, development, and management of one or more talent pools which are comprised of high performing individuals with the high potential to be appointed to work in these positions now and in the future (Collings \& Mellahi, 2009). The identification of relative potential of employees to contribute to the competitive performance and advantage of the firm in future (King \& Vaiman, 2019).

This paper is to develop a comprehensive framework for talent management extending the talent management literature. This paper is motivated by enormous literature on talent management for over a decade now, in order to explore the talent management in global context, this study will use a literature-based analysis to develop a framework from four perspective such as human centric culture, digital skills, employee wellbeing and human resource analytics which will lead to enhance the mechanism of talent management in the global organizations. The study will contribute theoretically and practically, the developed framework will strive to guide talent management practices within the companies.

\section{Rationale}

Talent management of knowledge workers and high potentials is of increasing strategic importance across the globe (Tymon et al., 2010). Talent management is the implementation of integrated strategies or systems designed to increase workplace productivity by developing improved processes for attracting, developing, retaining, and utilizing people with the required skills and aptitude to meet current and future business needs (Garg \& Rani, 2014). Talent management is of essence because organizations are able to successfully attract and maintain necessary talent. Moreover, talent identification and development help organizations identify employees who are capable of playing leadership roles in future. This approach emphasizes developing talent pools that have high leadership ability (Baheshtiffar, 2011). 
Talent management practices ensure that the right people want to join the company and effectively bring new, talented workers into the company. Moreover, talented workers are identified and valued, and incentives exist to retain them (Brundage and Koziel, 2010). Talent management is likely to be a challenge for organizations in all the major economies right across the world, with recent research suggesting that talent management challenges may even be more acute in the emerging markets (Tymon et al., 2010). In the exclusive philosophy of talent management, some proportions of an organization's employees are seen as the organization's "talent" (Stahl et al., 2012) and managed as a strategic resource of the firm, as they hold some form of valued human capital (King \& Vaiman, 2019).

Talent Management is an inclusive approach which focuses on (the talents of) all employees, or an exclusive approach aimed at attracting and retaining a select group of employees (Tansley, 2011). Subsequently, the outcomes of talent management and the talent management practices necessary to obtain the intended outcomes are key issues. In general, the talent management literature provides a rational and instrumental interpretation of the talent management process: talents are recruited and developed with a broad variety of talent management practices to direct their behavior in a direction that fits the organizational needs, and, as a result, the individual is happy and motivated, and individual and organizational performance increases (Thunnissen, 2016). The advancement in the field of talent management, this paper tried to analyze the talent management in global context from four perspectives such as human centric culture, digital skills, employee wellbeing and human resource analytics.

\section{Materials and Methods}

Talent has become an attractive source of competitive advantage and at the same time, many organizations are encountering talent shortages and finding it increasingly difficult to attract, manage, and retain talented people (Schuler et al., 2011). There exists a strong interest in amongst practitioners and scholars which leads to an increasing number of academic publications on talent management (Thunnissen et al., 2013). Global environment has not only changed the way business is conducted, but it has also created the need for organizations to manage their workforces in a global context (Briscoe et al., 2009).

The purpose of this paper is to contribute to the development of framework for talent management under the current global context so that the scholars and practitioners may make use to enhance their knowledge in the field of talent management. The framework for talent management will focus on human centric culture, digital skills, employee wellbeing and human resource analytics. The paper is built on the analysis and synthesis of scientific literature which enables to describe the phenomenon of the talent management and the current challenges in the global context and to develop a constructive framework for the talent management. 
This research follows integrative synthesis' procedure (Rousseau et al., 2008). The past literature was searched from various publication database, additionally full text from non-journal content such as book chapters, conference proceedings, case studies. The search protocol across all the data base involved searching articles titles for the term talent management, human centric culture, digital skills, employee wellbeing and human resource analytics.

\section{Framework for Talent Management}

Human Talent at every level is considered more important than ever to organizations that hope to raise their competitiveness, both globally and locally, as organizations face a global, complex, dynamic, highly competitive, and extremely volatile environment (Dayel et al., 2020). Talent management is a unique function that integrates all of the activities and responsibilities associated with the management of the talent lifecycle regardless of geography from attracting and acquiring talent to developing and retaining it (Schiemann, 2014). Talent management requires support from organizational management, existence of the right infrastructure, investment and human resource information system which is always up to date (Pella and Inayati, 2011). The framework designed based on the literature and the current global context faced by the organization which consist of four parts such as digital skills, human centric culture, human resource analytics, and employee wellbeing (Figure 1).

At present, for improving organizational performance, human resource is offering digitized solutions for business and employees, solutions that generate engagement and new experiences to employees. Digitization is one of the major challenges for global corporations is represented by attracting and retaining top talent (Mihalcea, 2017). A distinct problem is concerned with the fact that human resource divisions of companies are not actively involved in the acquisition of digital skills of employees, resulting in a fierce battle for talents (Spitzer et al., 2013).

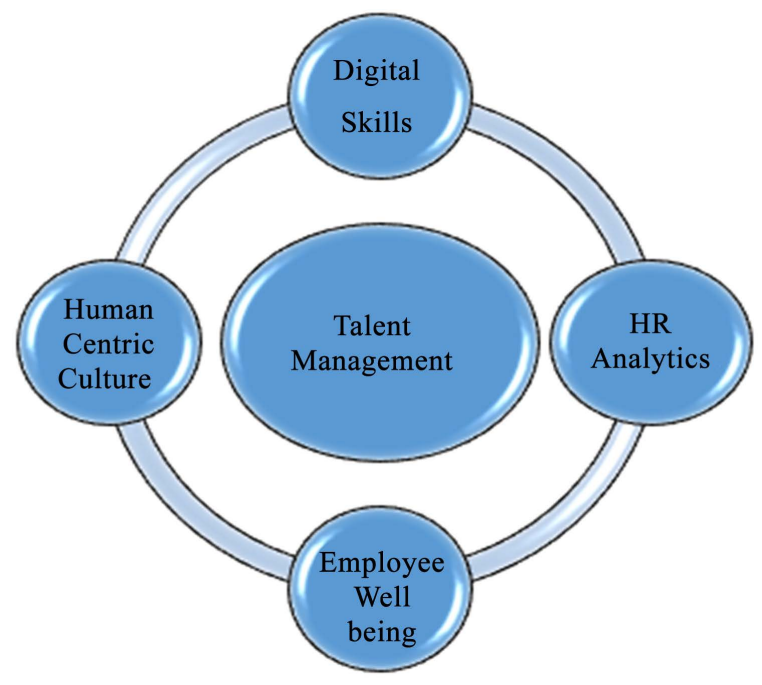

Figure 1. Talent management framework. 
Currently, the digital platforms represent the link between Big Data analytics and improvement of organizational performance in IT field (De Smet et al., 2016). In the current scenario, under the pressure of the business environment, youngsters will have to specialize in technology and be able to use automation platforms in their jobs (Mihalcea, 2017).

The workplaces of the future will be human centric instead of task centric, and the role of the employees is expected to increase, leading to an optimization of the production performance. In this new setting, it is the job that suits the skills, the experience, and the features of each employee (May et al., 2015). A human centric culture is characterized by permitting a unification of planning and implementation, expecting the user to be in control of the work process and the technology, fostering the utilization of human competencies, and ultimately ensuring a healthy and socially interactive working environment (Charles et al., 1990). Human centric culture plays a major role in the development of organizational innovation, especially when internal and external changes potentially threaten its business model (Ingram, 2019). Experiences of empathy were most often viewed as key signals of a human centric culture (Elsbach \& Stigliani, 2018). Human centric culture will shift the perspective from employer attributes to employee benefits and perceived value. Human centric culture may also be useful to acknowledge the different segments and employee needs among industries (Ronda et al., 2018).

Analytics in human resource management has been around for years (Marler \& Boudreau, 2017). Bassi (2011) argues that HR Analytics can be considered both as systematically reporting on an array of HR metrics or more sophisticated solutions, based on "predictive models" and what-if scenarios. HR Analytics "is an evidence-based approach for making better decisions on the people side of the business; it consists of an array of tools and technologies, ranging from simple reporting of HR metrics all the way up to predictive modeling". HR Analytics is associated with or can cause better performance and competitive advantage when it is unique and value producing (Marler \& Boudreau, 2017). It can be suggested that HR Analytics that measures the relationship between human resource management processes and people and business impact (Lawler \& Boudreau, 2015).

In the modern world where there are rising dependencies on global market forces places an ever-greater burden on those of working age in the delivery of products and services. This in turn has had a negative effect on the health and wellbeing of workers (Baptiste, 2008). Concentration on problems such as absenteeism and accidental injury is giving way to a broader vision of what a healthier and happier and more productive workforce can achieve in terms of higher performance and productivity (Economic and Social Research Council, 2006). Organizations are more productive and profitable if they are able to design a workplace that creates congruence in the line of sight between employer and employee interests. This means that the workplace is designed where employees 
believe they will benefit financially and psychologically if the organization is profitable and successful (Kossek et al., 2012). In such workplace employee wellbeing is enhanced through three steps. First, individuals feel they are recognized and valued for good work. Second, they believe they are able to have a career with their employer with mutual positive social exchange. Third, they are able to develop skills and knowledge that keeps them employable for a lifelong career. Thus, designing the workplace to promote employee well-being must be coupled with a high-performing caring culture as this ensures employability for employees (Brough et al., 2009).

\section{Discussion}

Talent management has emerged as the biggest challenge facing organizations, which is the scarcity of talented workers possessing the necessary skills of a globally competitive workforce (Doh et al., 2011). Today, human capital at every level is considered more important than ever to organizations that hope to raise their competitiveness, both globally and locally, as organizations face a global, complex, dynamic, highly competitive, and extremely volatile environment (Dayel et al., 2020). By highlighting talent identification as one of the talent management practices, some scholars have pointed out that talent management is primarily concerned with employees who add value to the organization. Those employees who are identified by the organizations as talent are those who possess the potential to have a significant influence on organizational success (McDonnell \& Collings, 2011, Arris et al., 2013, Van et al., 2017, Bolander et al., 2017). Talent Management requires a change in mindset to focus on potential outputs. Profitability is one of the most important outputs that organizations seek to achieve (Dayel et al., 2020).

As emerging markets grow and become integrated into the global marketplace, the management practices of developed countries have gradually transferred to the developing countries. As a result, in relation to recruitment, Western practices have taken root in the private sector in terms of employing the most capable employees for developing the organization (Doh et al., 2011). In the realm of talent management, companies have begun to deal with the recruitment of individuals based on the competition for talent, as companies seek to maintain a competitive advantage by leveraging their understandings of the linkages between talent management and overall firm performance (Bowen \& Ostroff, 2004). Talent retention is another talent management practice, one of the top priorities in organizations agenda to reduce talent employee's turnover (Oladapo, 2014). Retention is a critical element in an organization's approach to talent management, which is "the implementation of integrated strategies or systems designed to increase workplace productivity by developing improved processes for attracting developing, improving, retaining, and utilizing people with the required skills and aptitude to meet current and future business needs" (Lockwood, 2006). Organizations to use exclusive talent management approach 
that aim to create long-term employment relationships with talent by fostering their commitment to the organization (Dayel et al., 2020).

Management of talented employees is very challenging; it is associated with a multiplicity of outcomes (Dries et al., 2012). The ultimate aim of talent management is to make maximum use of talented employees and to utilize them appropriately (Mensah, 2015). Managing talented employees helps to reduce expenses and labour costs, to improve competitiveness and efficiency, to solve organizational problems and ultimately helps to maximize return on investment (Jackson et al., 2009). The paper has contributed to the existing knowledge of talent management in four ways such as digital skills, human centric culture, human resource analytics and employee wellbeing. First the Digital skills are discussed as the ability to apply said knowledge and skills to various life contexts, from personal to professional (Iordache et al., 2017). Second the human centric culture is useful to improve the knowledge and the capabilities of employee regardless of age and role (May et al., 2015). Third human resource analytics played a central role in determining or implementing human resource strategy (Marler \& Boudreau, 2017). Finally, the employee wellbeing at work appears to be a critical factor in determining employee attitudes to change, therefore the central role played by trust in management and supervisory support in the promotion of employee wellbeing at work should be widely acknowledged (Baptiste, 2008).

\section{Limitation \& Future Research}

Despite the growing popularity of talent management and over a decade of debate and hype, the concept of talent management remains unclear (Nijs et al., 2014; Van et al., 2017). The research conducted by Arris, Cascio and Paauwe (2013). Consequently, even though business and consulting firms in the private sector have been driving talent management as a strategic priority, there seems to be an overall lack of theoretical frameworks in the academic field. Overall, there is a need for talent management framework in every organization. This paper attempted to develop a framework for talent management however it does not use qualitative research to seek better understanding how the framework in the organizational context. This framework also suggests that future research work will determine empirical support which will help the global organization to face the challenges in the talent management in the competitive environment. The future investigation includes analyses at multiple levels of the organization and the specification of the impact of talent-related decisions throughout the organization. Along with implications for the researchers and practitioner the paper suggests to directions for future research to further enrich the field of talent management.

\section{Conclusion}

Talent management is to ensure employee performance and ultimately organiza- 
tional performance; it nonetheless leads to talent management outputs which serve as antecedents. It has been observed that talent management leads to employee performance while at the same time it helps organizations respond to challenges, enter new markets, and move ahead of the competition (Mensah, 2015). For countries operating in multinational environments, this framework and measurement approach can be applied to understand unique challenges in the current global scenario that may reflect both the capabilities and behaviors of human capital in those countries. This paper has contributed to the conceptualization of talent management focusing on digital skills, human resource analytics, human centric culture and employee wellbeing and will help to improve the theory, research, and practice in all global organizations. From this framework, several areas such as employee growth, employee performance, employee appreciation, satisfaction, culture, success, feedback, and recognition can be pursued to be beneficial to the research and practice in human resource management.

\section{Conflicts of Interest}

The author declares no conflicts of interest regarding the publication of this paper.

\section{References}

Arris, A. A., Cascio, W. F., \& Paauwe, J. (2013). Talent Management: Current Theories and Future Directions. Journal of World Business, 49, 173-179. https://doi.org/10.1016/j.jwb.2013.11.001

Baheshtiffar, M. (2011). Role of Career Competencies in Organization. European Journal of Economics Finance and Administrative Sciences, 42, 201-221.

Baptiste, N. R. (2008). Tightening the Link between Employee Wellbeing at Work and Performance. Management Decision, 46, 284-309. https://doi.org/10.1108/00251740810854168

Bassi, L. (2011). Raging Debates in HR Analytics. People and Strategy, 34, 14-18.

Bolander, P., Werr, A., \& Asplund, K. (2017). The Practice of Talent Management: A Framework and Typology. Personnel Review, 46, 1523-1551. https://doi.org/10.1108/PR-02-2016-0037

Bowen, D. E., \& Ostroff, C. (2004). Understanding HRM-Firm Performance Linkages: The Role of the "Strength" of the HRM System. Academy of Management Review, 29, 203 221. https://doi.org/10.5465/amr.2004.12736076

Briscoe, D., Schuler, R., \& Claus, E. (2009). International Human Resource Management (3rd ed.). London: Routledge. https://doi.org/10.4324/9780203866962

Brough, P., O’Driscoll, M., Kalliath, T., Cooper, C. L., \& Poelmans, S. A. (2009). Workplace Psychological Health: Current Research and Practice. Edward Elgar Publishing. https://doi.org/10.4337/9781781952672

Brundage, H., \& Koziel, M. (2010). Retaining Top Talent Still a Requirement for Firms: Focus on People Now to Keep Turnover Costs down When the Economy Improves. Journal of Accountancy, 209, Article No. 38.

Caligiuri, P., \& Tarique, I. (2009). Predicting Effectiveness in Global Leadership Activi- 
ties. Journal of World Business, 44, 336-346. https://doi.org/10.1016/j.jwb.2008.11.005

Charles, T., Charles, R., \& Roulstone, A. (1990). Prospects and Conditions for Anthropocentric Production Systems in Britain. APS-Research Papers Series, 8.

Collings, D. G., \& Mellahi, K. (2009). Strategic Talent Management: A Review and Research Agenda. Human Resource Management Review, 19, 304-313. https://doi.org/10.1016/j.hrmr.2009.04.001

Dayel, W. A., Debrah, Y. A., \& Mulyata, J. (2020). To Explore the Effect of Talent Management Developments in Saudi Healthcare Sector. Management, 8, 1-13. https://doi.org/10.17265/2328-2185/2020.01.001

De Smet, A., Lund, S., \& Schaninger, W. (2016). Organizing for the Future. McKinsey Quarterly, 1, 30-43.

Doh, J. P., Tymon Jr., W. G., \& Stumpf, S. A. (2011). Talent Management in India. In D. G. Collings, H. Scullion, \& P. M. Caligiuri (Eds.), Global Talent Management (pp. 129147). New York, NY: Routledge.

Dries, N., Van Acker, F., \& Verbruggen, M. (2012). How “Boundaryless" Are the Careers of High Potentials, Key Experts and Average Performers? Journal of Vocational Behavior, 81, 271-279. https://doi.org/10.1016/j.jvb.2011.10.006

Economic and Social Research Council (2006). Health and Well-Being at Work of Working Age People, Seminar Series: Mapping the Public Policy Landscape. Swindon: Economic and Social Research Council.

Elsbach, K. D., \& Stigliani, I. (2018). Design Thinking and Organizational Culture: A Review and Framework for Future Research. Journal of Management, 44, 2274-2306. https://doi.org/10.1177\%2F0149206317744252

Ford, J., Harding, N., \& Stoyanova Russell, D. (2010). Talent Management and Development. An Overview of Current Theory and Practice.

Garg, D., \& Rani, K. (2014). Talent Management: Empirical Research Results. International Journal of Management and Commerce Innovations, 2, 289-295.

Ingram, K. L. (2019). Power and Culture in Human-Centric Innovation Ecosystems. Journal of Management and Training for Industries, 6, 1-16.

Iordache, C., Mariën, I., \& Baelden, D. (2017). Developing Digital Skills and Competences: A Quick-Scan Analysis of 13 Digital Literacy Models. Italian Journal of Sociology of Education, 9, 6-30.

Jackson, S. E., Schuler, R. S., \& Werner, S. (2009). Managing Human Resources (p. 358). Mason, $\mathrm{OH}$ : South-Western Cengage Learning.

King, K. A., \& Vaiman, V. (2019). Enabling Effective Talent Management through a Macro-Contingent Approach: A Framework for Research and Practice. BRQ Business Research Quarterly, 22, 194-206. https://doi.org/10.1016/j.brq.2019.04.005

Kossek, E. E., Kalliath, T., \& Kalliath, P. (2012). Achieving Employee Wellbeing in a Changing Work Environment: An Expert Commentary on Current Scholarship. International Journal of Manpower, 33, 738-753. https://doi.org/10.1108/01437721211268294

Lawler III, E. E., \& Boudreau, J. W. (2015). Global Trends in Human Resource Management: A Twenty-Year Analysis. St, Redwood City, CA: Stanford University Press.

Lockwood, N. R. (2006). Talent Management: Driver for Organizational Success. $H R$ Magazine, 51, 1-11.

Marler, J. H., \& Boudreau, J. W. (2017). An Evidence-Based Review of HR Analytics. The International Journal of Human Resource Management, 28, 3-26. 
https://doi.org/10.1080/09585192.2016.1244699

May, G., Taisch, M., Bettoni, A., Maghazei, O., Matarazzo, A., \& Stahl, B. (2015). A New Human-Centric Factory Model. Procedia CIRP, 26, 103-108. https://doi.org/10.1016/j.procir.2014.07.112

McDonnell, A., \& Collings, D. G. (2011). The Identification and Evaluation of Talent in MNES. 72-89.

Mensah, J. K. (2015). A “Coalesced Framework" of Talent Management and Employee Performance. International Journal of Productivity and Performance Management, 64, 544-566. https://doi.org/10.1108/IJPPM-07-2014-0100

Mihalcea, A. (2017). Employer Branding and Talent Management in the Digital Age. Management Dynamics in the Knowledge Economy, 5, 289-306. https://doi.org/10.25019/MDKE/5.2.07

Nijs, G., Gallardo-Gallardo, G., Dries, S., \& Sels, M. (2014). What Is the Meaning of Talent in the World of Work? Human Resource Management Review, 23, 290-300. https://doi.org/10.1016/j.hrmr.2013.05.002

Oladapo, V. (2014). The Impact of Talent Management on Retention. Journal of Business Studies Quarterly, 5, 19-36.

Pella, D. A., \& Inayati, A. (2011). Talent Management (Mengembangkan SDM untuk mencapai pertumbuhan dan kinerja prima). Jakarta: PT Gramedia Pustaka Utama.

Ronda, L., Valor, C., \& Abril, C. (2018). Are They Willing to Work for You? An Employee-Centric View to Employer Brand Attractiveness. Journal of Product \& Brand Management, 27, 573-596. https://doi.org/10.1108/JPBM-07-2017-1522

Rousseau, D. M., Manning, J., \& Denyer, D. (2008). 11 Evidence in Management and Organizational Science: Assembling the Field's Full Weight of Scientific Knowledge through Syntheses. Academy of Management Annals, 2, 475-515.

https://doi.org/10.5465/19416520802211651

Schiemann, W. A. (2014). From Talent Management to Talent Optimization. Journal of World Business, 49, 281-288. https://doi.org/10.1016/j.jwb.2013.11.012

Schuler, R. S., Jackson, S. E., \& Tarique, I. (2011). Global Talent Management and Global Talent Challenges: Strategic Opportunities for IHRM. Journal of World Business, 46, 506-516. https://doi.org/10.1016/j.jwb.2010.10.011

Spitzer, B., Morel, V., Buvat, J., Kvj, S., Bisht, A., \& Radhakrishnan, A. (2013). The Digital Talent Gap: Developing Skills for Today's Digital Organizations. Capgemini Consulting.

Stahl, G., Björkman, I., Farndale, E., Morris, S. S., Paauwe, J., Stiles, P. et al. (2012). Six Principles of Effective Global Talent Management. Sloan Management Review, 53, 25-42.

Tansley, C. (2011). What Do We Mean by the Term “Talent” in Talent Management? Industrial and Commercial Training, 43, 266-274. https://doi.org/10.1108/00197851111145853

Thunnissen, M. (2016). Talent Management: For What, How and How Well? An Empirical Exploration of Talent Management in Practice. Employee Relations, 38, 57-72. https://doi.org/10.1108/ER-08-2015-0159

Thunnissen, M., Boselie, P., \& Fruytier, B. (2013). A Review of Talent Management: "Infancy or Adolescence?" The International Journal of Human Resource Management, 24, 1744-1761. https://doi.org/10.1080/09585192.2013.777543

Tymon Jr., W. G., Stumpf, S. A., \& Doh, J. P. (2010). Exploring Talent Management in India: The Neglected Role of Intrinsic Rewards. Journal of World Business, 45, 109-121. https://doi.org/10.1016/j.jwb.2009.09.016 
Van Zyl, E. S., Mathafena, R. B., \& Ras, J. (2017). The Development of a Talent Management Framework for the Private Sector. SA Journal of Human Resource Management, 15, Article No. a820. https://doi.org/10.4102/sajhrm.v15i0.820 